\title{
Perencanaan Pembangunan Daerah Dalam Rangka Meningkatkan Daya Saing (Studi Pada Provinsi Bengkulu)
}

\author{
Adriani Ginting ${ }^{1 *}$, Bambang Supriyono ${ }^{2}$, Irwan Noor ${ }^{2}$ \\ ${ }^{1}$ Magister Administrasi Publik, Fakultas Ilmu Administrasi, Universitas Brawijaya \\ 2 Fakultas Ilmu Administrasi, Universitas Brawijaya
}

\begin{abstract}
Abstrak
Daya saing menjadi salah satu tujuan pembangunan yang krusial karena berkaitan dengan kemampuan suatu daerah dalam menarik tenaga kerja yang terampil dan investasi baik dari dalam maupun luar negeri. Beberapa penelitian terdahulu menunjukkan bahwa Bengkulu merupakan salah satu provinsi dengan tingkat daya saing yang rendah bila dibandingkan dengan 32 provinsi lain di Indonesia. Rendahnya daya saing ini juga ditunjukkan oleh tingginya angka kemiskinan dan pengangguran di provinsi Bengkulu. Tulisan ini bertujuan untuk membahas daya saing daerah dengan menganalisis perencanaan pembangunan daerah yang dilaksanakan di provinsi Bengkulu terkait dengan usaha peningkatan daya saing dan penentuan prioritas pembangunan yang dapat dilaksanakan untuk meningkatkan daya saing tersebut. Data dan informasi diperoleh melalui survei, wawancara dan dokumentasi yang kemudian dianalisis dengan triangulasi data, metode Analytic Network Process (ANP) dan Kendall's Coefficient of Concordance. Hasil penelitian menunjukkan bahwa perbaikan aspek kelembagaan pemerintah daerah menjadi prioritas dalam meningkatkan daya saing di provinsi Bengkulu disusul dengan aspek ekonomi, sosial dan lingkungan. Masalah yang dihadapi dalam perencanaan khususnya untuk meningkatkan daya saing adalah kualitas perencana, koordinasi antar instansi dan proses evaluasi dan monitoring. Dengan demikian untuk meningkatkan daya saing, kebijakan pemerintah dapat diarahkan pada perbaikan kelembagaan yang salah satunya dengan membangun kapasitas dan menyelesaikan masalah-masalah yang berkaitan dengan perencanaan tersebut.
\end{abstract}

Kata kunci: Daya Saing Daerah, Perencanaan, Prioritas, Analytic Network Proces(ANP)

Abstract

Regional competitiveness becomes one of the crucial development objectives since it relates to the ability of a region to attract both of a skilled workforce and investments from inside and outside of the country. Several previous studies showed that Bengkulu is one of the provinces with low levels of competitiveness compared with other 32 provinces in Indonesia. The low level of competitiveness is also demonstrated by high rates of poverty and unemployment. This paper aims to examine the regional competitiveness by analyzed regional development plans which implemented in province of Bengkulu that associated with enhancement of regional competitiveness and determination of development priorities which can be implemented to improve regional competitiveness in province of Bengkulu. Data and information were gained through surveys, interviews and documentation analyzed by data triangulation, Analytical Network Process (ANP)and Kendall's Coeffiecient of Concordance. Result of data tabulation showed that the improvement of local government institutions is a priority to improve competitiveness in the provinces of Bengkulu followed by economy, social and environment sector. The problems that encountered in planning in particular to improve competitiveness is the quality and quantity of planners, coordination between institution and process of evaluation and monitoring. Thus, to improve regional competitiveness, government policy can be directed to institutional improvement with capacity building and fixing the problems which related to planning.

Keywords: Regional Competitiveness, Planning, Priority, , Analytic Network Process(ANP)

\section{PENDAHULUAN}

Daya saing daerah menjadi salah satu tujuan penting dalam proses pembangunan karena pada kenyataannya sebuah daerah, layaknya sebuah perusahaan, juga bersaing dengan daerah lain. Walaupun setiap daerah memiliki karakteristik, potensi dan permasalahan yang berbeda namun setiap daerah saling bersaing terutama dalam

Alamat KorespondensiPenulis:

Adriani Ginting

Email : adriani.ginting14@gmail.com

Alamat : Jl. MT Haryono No.163 Malang tiga hal yakni pertama menarik tenaga kerja yang terdidik dan terampil. Kedua, menarik investasi baik para investor yang berasal dari dalam maupun luar negeri dan Ketiga menarik para pengusaha (entrepreneur) untuk mengembangkan usaha di daerah tersebut.

Ketiga hal tersebut menjadi penting karena tenaga kerja, para pengusaha (entrepreneur) maupun investor adalah aktor penting dalam menggerakkan roda perekonomian suatu daerah. Krugman (2003) menyatakan bahwa daerah yang kondusif dan produktif tidak hanya mampu 
mempertahankan tenaga kerja dan modal yang ada di daerahnya tetapi juga akan mampu menarik tenaga kerja dan modal dari daerah lain. Tenaga kerja dan modal yang mengalir masuk ke daerah tersebut akan mendorong peningkatan produktivitas sehingga daerah tersebut akan mampu untuk terus maju dan menerima manfaat dari daerah lain. ${ }^{1}$

Dari sisi empirik, arti pentingnya daya saing daerah ditunjukkan dari ketimpangan pembangunan antar daerah yang terjadi di Indonesia. Hal ini dibuktikan dari pembangunan di barat Indonesia lebih baik dari pembangunan di bagian timur. Hasil penelitian tentang tingkat daya saing seluruh provinsi di Indonesia yang dilakukan oleh Khee G. Tan pada tahun 2013 juga menunjukkan bahwa daerah dengan tingkat daya saing tertinggi didominasi oleh provinsi-provinsi yang berada di sebelah barat Indonesia. ${ }^{2}$ Kedua hal tersebut membuktikan bahwa peningkatan daya saing penting dilakukan setiap pemerintah daerah guna mengurangi ketimpangan pembangunan antardaerah di Indonesia.

Hubungan antara ketimpangan pembangunan antardaerah dengan perbedaan tingkat daya saing daerah dibuktikan pula oleh penelitian yang dilakukan Charles dan Zegara (2014) yang mengukur tingkat daya saing daerah di Peru dengan menggunakan Data Envelopment Analysis (DEA). Penelitian Charles dan Zegara tersebut menyimpulkan bahwa daerah dengan tingkat daya saing yang tinggi (insfrastruktur, kelembagaan, sumber daya manusia dan lingkungan bisnis yang lebih baik) memiliki tingkat pertumbuhan ekonomi yang lebih baik bila dibandingkan dengan daerah lain; konsep daya saing tidak hanya untuk mengevaluasi mengapa suatu daerah dapat tumbuh lebih cepat dibandingkan dengan daerah lain tetapi juga menjelaskan mengapa distribusi pendapatan suatu negara atau daerah lebih merata bila dibandingkan dengan negara atau daerah yang lain. ${ }^{3}$

Disamping ketimpangan pembangunan antardaerah, peningkatan daya saing juga berkaitan erat dengan globalisasi dan penerapan Masyarakat Ekonomi Asean (MEA) pada akhir tahun 2015 di negara-negara asia tenggara. Seperti yang dikemukakan Imawan (2002) bahwa globalisasi dan perdagangan bebas bukanlah sebuah konsep yang netral dimana setiap negara memiliki hak dan kesempatan yang sama untuk mempengaruhi dinamika internasional. Globalisasi mengandung makna dominasi yang artinya bahwa pemerintah atau negara dapat terjepit antara suasana kompetisi yang berkembang pada tataran masyarakat dengan ancaman dominasi yang menantinya ada tataran internasional. Pemerintah dalam hal ini, menjadi perisai agar dominasi internasional tidak menyentuh suasana kompetisi di tingkat lokal maupun nasional dan pada saat yang sama menjadi ujung tombak pemaksimalan kepentingan nasional di tingkat internasional. Dengan demikian peran pemerintah untuk menumbuhkan dan meningkatkan daya saing dapat dilihat dari tiga sisi yakni pertama menjaga kompetensi antarpengusaha atau antarproduk di dalam daerah agar dapat terus tumbuh dan berkembang sehingga dapat bertahan dari serbuan produk atau jasa dari daerah atau negara lain (unggul di dalam daerah sendiri). Kedua mengembangkan produk dan jasa yang ada untuk dapat bersaing di pasar internasional dan Ketiga adalah agar daerah mampu menarik tenaga kerja, pengusaha atau investor untuk mengembangkan perekonomian daerah. ${ }^{4}$

Peningkatan daya saing juga menjadi isu yang penting berkaitan dengan pelaksanaan amanah Undang-Undang Nomor 23 Tahun 2014 tentang Pemerintahan Daerah khususnya pasal 258 yang menyebutkan bahwa salah satu tujuan pembangunan adalah meningkatkan daya saing daerah. Selain itu ketentuan normatif lainnya yang mengatur peningkatan daya saing adalah undang-undang tentang rencana pembangunan jangka panjang nasional, yang menyebutkan bahwa sasaran pembangunan jangka menengah nasional periode 2010-2014 adalah mencapai penguatan daya saing perekonomian dan periode 2015-2019 pembangunan diarahkan untuk mencapai daya saing perekonomian yang didasarkan pada keunggulan dan kualitas sumber daya alam dan sumber daya manusia.

Peningkatan daya saing hanya dapat dicapai melalui perbaikan faktor-faktor input yakni faktor yang menunjukkan kemampuan daerah untuk membangun perekonomiannya baik faktor yang menjadi penentu kesuksesan (succsess determinant) peningkatan daya saing maupun faktor-faktor daya saing (competitiveness factors) itu sendiri. Faktor-faktor input ini akan menentukan kinerja perekonomian (output) dalam jangka pendek dan peningkatan kesejahteraan masyarakat (outcome) dalam jangka panjang. Untuk itu, untuk menganalisis daya saing daerah dapat dilakukan dengan melihat faktor-faktor input yang menggerakkan perekonomian daerah. 
Gambaran yang cukup jelas mengenai faktorfaktor yang membangun daya saing daerah dikemukakan oleh Lengyel dan Rechnitzer (2013) dengan teori piramida daya saing. Lengyel dan Rechnitzer menyatakan bahwa daya saing dapat dilihat dari tiga hal yakni pendapatan daerah, tingat produktivitas tenaga kerja dan tingkat pengangguran. Pencapaian ketiga hal tersebut ditentukan oleh faktor kegiatan penelitian dan pengembangan, sumber daya manusia, investasi, kelembagaan dan perdagangan. Sedangkan yang menjadi penentu kesuksesan peningkatan daya saing adalah struktur ekonomi dan sosial di daerah, pembuat kebijakan, aktivitas inovatif dan kewirausahaan, aksesibilitas dan infrastruktur, lingkungan, tenaga kerja yang terampil dan budaya masyarakat setempat. ${ }^{5}$

Banyak penelitian yang berusaha membuktikan faktor-faktor yang berpengaruh pada pertumbuhan ekonomi dan peningkatan daya saing suatu daerah. Penelitian Ron Martin pada tahun 2005 membuktikan bahwa kuallitas sumber daya manusia, potensi sumber daya alam, perbaikan kualitas infrastruktur, pengembangan inovasi dan kegiatan penelitian dan pengembangan mampu memberikan kontribusi positif bagi peningkatan perekonomian daerah. ${ }^{6}$ Penelitian yang dilakukan Paul Plummer (2014) membuktikan bahwa daerah-daerah yang melakukan peningkatan kualitas dan kuantitas infrastruktur, menumbuhkan kegiatan inovasi teknologi, dan memperkuat kondisi lingkungan lokal dan menciptakan regim perencanaan yang kondusif mampu mencapai pertumbuhan ekonomi yang lebih baik dibandingkan dengan daerah lain. ${ }^{7}$

Pembangunan di provinsi Bengkulu masih jauh tertinggal bila dibandingkan dengan daerah lain. Hal ini dibuktikan oleh penelitian yang dilaksanakan oleh Laboratorium Penelitian, Pengabdian pada Masyarakat dan Pengkajian Ekonomi (LP3E) Fakultas Ekonomi Universitas Padjadjaran dan Pusat Pendidikan dan Studi Kebanksentralan (PPSK) Bank Indonesia pada tahun 2007 yang menunjukkan bahwa tingkat daya saing kabupaten/kota di Provinsi Bengkulu pada umumnya menempati posisi di kuadran III yakni kategori daerah yang karakteristik input dan outputnya berada di bawah rata-rata input dan output nasional.Lima tahun kemudian, hasil penelitian Khee G Tan (2013) yang mengukur tingkat daya saing 33 provinsi di Indonesia, menempatkan provinsi Bengkulu di peringkat 28 dari 33 provinsi.
Rendahnya tingkat daya saing ini juga dapat dilihat dari pendapatan daerah yang rendah bila dibandingkan dengan daerah lain di Indonesia. Tingkat pendapatan domestik regional bruto provinsi Bengkulu pada tahun 2013 adalah Rp27.388.245,81 juta. Dengan tingkat pendapatan tersebut, provinsi Bengkulu hanya menyumbangkan sekitar $0,36 \%$ dari total pendapatan nasional. Disamping itu, walaupun pendapatan daerah mengalami peningkatan namun tidak diikuti dengan peningkatan kemakmuran masyarakat. Jumlah penduduk miskin di Provinsi Bengkulu meningkat yakni sebanyak 2.812.000 jiwa pada tahun 2010 menjadi 3.325.000 jiwa pada tahun 2013.

Pendesentralisasian kewenangan untuk merencanakan pembangunan di daerah pada dasarnya dilakukan agar pembangunan lebih tepat sasaran. Seperti yang dikemukakan Kumar (2001:2) bahwa desentralisasi perencanaan sebagai persepsi yang lebih baik atas kebutuhan lokal, memungkinkan proses formulasi kebijakan untuk memperoleh lebih banyak informasi, memberikan ruang yang lebih luas bagi masyarakat yang menjadi sasaran pembangunan untuk bersuara dalam proses pembuatan keputusan dan pelaksanaan untuk mencapai koordinasi dan integrasi yang lebih baik antara program yang dapat menampung atau menjawab kebutuhan masyarakat. ${ }^{8}$ Namun kondisi-kondisi tersebut diatas menunjukkan bahwa pelaksanaan otonomi daerah khususnya pendesentralisasian kewenangan untuk merencanakan pembangunan daerah belum mencapai tujuan yang diharapkan.

Dalam teori perencanaan ada dua pandangan yang membahas mengenai perencanaan yang baik. Pertama teori prencanaan rasional yang menyatakan bahwa perencanaan yang baik adalah perencanaan yang disusun berdasarkan akurasi data, hasil pengamatan (observasi yang mendalam) dan berdasarkan pengalaman atau hasil evaluasi yang diperoleh dari kasus sebelumnya. Kedua, teori perencanaan partisipatif/komunikatif yang menyatakan bahwa perencanaan yang baik adalah perencanaan yang melibatkan masyarakat dalam proses perencanaan. Pada prakteknya kedua teori tersebut telah dilaksanakan oleh pemerintah daerah dalam menyusun perencanaan pembangunan. Oleh karena itu, perencanaan seharusnya menghasilkan pencapaian pembangunan yang signifikan dan lebih baik dari tahun ke tahun.

Disisi lain Faludi (1973) menyatakan ada dua teori dalam perencanaan yang dapat digunakan 
untuk melihat masalah yang dihadapi dalam perencanaan yakni teori substantif dan teori prosedural. ${ }^{9}$ Teori substansif (Theory in Planning) memandang masalah perencanaan terletak pada ketidakmampuan para perencana untuk memahami letak akar masalah yang sesungguhnya dihadapi masyarakat dan pada akhirnya berakibat pada ketidakmampuan para perencana dalam menyusun rencana yang efektif untuk mengatasi dan mengantisipasi masalah yang akan datang.

Sedangkan teori prosedural (Theory of Planning) memandang perencanaan sebagai sebuah proses yang terkait dengan kapasitas perencana, operasionalisasi prosedur dalam penyusunan rencana dan kelembagaan yang bertanggung jawab menyusun dan menetapkan rencana. Berdasarkan pengertian tersebut maka apabila dipandang dari sudut teori prosedural maka inti masalah perencanaan adalah pada proses pembuatan rencana itu sendiri yang didalamnya terdapat serangkaian prosedur serta melibatkan banyak pihak. Proses yang panjang dan banyaknya pihak yang terlibat tersebut seringkali menyebabkan perencanaan menjadi tidak efektif.

Berdasarkan hal tersebut maka penelitian ini bertujuan menganalisis perencanaan yang dilaksanakan di Provinsi Bengkulu terkait dengan peningkatan daya saing dan menentukan prioritas pembangunan yang dapat dilakukan untuk meningkatkan daya saing di Provinsi Bengkulu.

\section{METODE PENELITIAN}

Metode yang digunakan adalah metode deksriptif dengan pendekatan kuantitatif karena bertujuan untuk menganalisis perencanaan peningkatkan daya saing dan menentukan prioritas untuk mencapai peningkatan daya saing tersebut.

Data yang telah diperoleh kemudian dianalisis dengan menggunakan Analytical Network Process $(\mathrm{ANP})^{10}$ dan Kendall's Coefficient of Concordance serta triangulasi data (kuisioner, wawancara dan dokumentasi) untuk menganalisis dan menentukan prioritas pembangunan untuk meningkatkan daya saing daerah di Provinsi Bengkulu.

Metode Pengumpulan Data

Metode pengumpulan data yang digunakan adalah metode survei. Data primer diperoleh melalui kuisioner sedangkan data sekunder diperoleh dari hasil wawancara dan pengumpulan dokumen yang berkaitan dengan masalah penelitian.

Populasi penelitian adalah seluruh unsur pemerintah daerah, akademisi, pengusaha dan lembaga keuangan yang ada di provinsi Bengkulu. Teknik sampling menggunakan teknik nonprobability sampling dengan metode purposive sampling. Adapun kriteria yang digunakan untuk memilih responden adalah pihak-pihak yang mewakili pemerintah daerah, akademisi, pengusaha dan lembaga keuangan yang dinilai menguasai bidang perencanaan pembangunan di daerah dan mengetahui dengan baik kondisi daerah provinsi Bengkulu baik dari sisi ekonomi maupun sosial.

Variabel yang digunakan untuk menentukan prioritas dalam peningkatan daya saing daerah adalah:

1. Variabel ekonomi dengan indikator modal, investasi, teknologi, kinerja sektoral, sumber daya manusia, infrastruktur dan inovasi.

2. Variabel sosial dengan indikator pendidikan, kesehatan, budaya dan keamanan.

3. Variabel lingkungan dengan indikator sumber daya alam, kondisi alam dan lokasi.

4. Variabel kelembagaan dengan indikator pelayanan publik, kebijakan pemerintah, hambatan birokrasi dan pengeluaran pemerintah.

Masing-masing variabel dan indikator tersebut dibandingkan untuk memperoleh prioritas baik antarvariabel maupun antarindikator. Dalam analisis ANP, variabel penelitian ini disebut dengan istilah klaster dan indikator penelitian disebut dengan elemen. Penentuan nilai prioritas baik antarvariabel dan antarindikator dilakukan dengan menggunakan kuisioner perbandingan berpasangan (pairwise comparison) dengan pembobotan jawaban sebagai berikut:

Tabel 1. Skala Penilaian Perbandingan berpasangan dan Penjelasannya

\begin{tabular}{llll}
\hline Bobot & \multicolumn{1}{c}{ Pengertian } & \multicolumn{2}{c}{ Penjelasan } \\
\hline 1 & $\begin{array}{l}\text { Berpengaruhsama } \\
\text { besar (equal } \\
\text { importance) }\end{array}$ & $\begin{array}{l}\text { Elemen yang } \\
\text { diperbandingkanber } \\
\text { pengaruhsamabesar }\end{array}$ \\
\hline 3 & $\begin{array}{l}\text { Berpengaruhsediki } \\
\text { tlebihbesar } \\
\text { (moderate } \\
\text { importance) }\end{array}$ & $\begin{array}{l}\text { Elemen yang satu } \\
\text { sedikit lebih besar } \\
\text { pengaruhnya } \\
\text { dibandingkan } \\
\text { denganelemen lain }\end{array}$ \\
\hline 5 & $\begin{array}{l}\text { Berpengaruh lebih } \\
\text { besar (strong } \\
\text { importance) }\end{array}$ & $\begin{array}{l}\text { Elemen yang satu } \\
\text { lebih } \\
\text { pengaruhnya }\end{array}$ \\
\hline
\end{tabular}




\begin{tabular}{|c|c|c|}
\hline & & $\begin{array}{l}\text { dibandingkan } \\
\text { dengan elemen lain }\end{array}$ \\
\hline 7 & $\begin{array}{l}\text { Berpengaruh } \\
\text { sangat lebih besar } \\
\text { (very strong or } \\
\text { demonstrated } \\
\text { importance) }\end{array}$ & $\begin{array}{l}\text { Elemen yang satu } \\
\text { lebih besar pengaruh } \\
\text { dan dominasinya } \\
\text { secara praktis lebih } \\
\text { terlihat bila } \\
\text { dibandingkan } \\
\text { dengan elemenlain } \\
\end{array}$ \\
\hline 9 & $\begin{array}{l}\text { Berpengaruhmutla } \\
\mathrm{k} \text { (extreme } \\
\text { importance) }\end{array}$ & $\begin{array}{l}\text { Elemen yang satu } \\
\text { mutlak berpengaruh } \\
\text { bila dibandingkan } \\
\text { denganelemen lain }\end{array}$ \\
\hline $\begin{array}{l}2,4,6 \\
\text { dan } 8\end{array}$ & $\begin{array}{l}\text { Bernilai diantara } \\
\text { (nilai tengah) dua } \\
\text { perbandingan } \\
\text { yang } \\
\text { berdampingan }\end{array}$ & $\begin{array}{l}\text { antarelemen yang } \\
\text { dibandingkan } \\
\text { memiliki nilai antara } \\
\text { (kompromi nilai yang } \\
\text { satu dengan nilai } \\
\text { pengaruh lainnya) }\end{array}$ \\
\hline
\end{tabular}

Sumber :Saaty, 2006.

\section{a. Geometric Mean}

Untuk menentukan hasil konsensus pendapat dari para responden maka dilakukan perhitungan dengan menggunakan geometric mean dengan formula sebagai berikut:

$$
G=\sqrt[m]{\prod_{k=i}^{m} \text { ain }}=\sqrt[m]{a_{1} x a_{2} x a_{n}}
$$

Hasil geometric mean ini kemudian akan diinput dan diolah dengan menggunakan perangkat lunak super decision untuk menentukan prioritas pembangunan dalam rangka meningkatkan daya saing di provinsi Bengkulu.

\section{b. Rater Agreement}

Untuk menentukan tingkat kesepakatan para responden (rater agreement) atas prioritas yang diperoleh maka digunakan Koefisien Konkordansi Kendall (W). Nilai koefisien Kendall (W) berkisar antara 0 sampai dengan 1 . Nilai Wsama dengan 1 menunjukkan kesesuian pendapat yang sempurna sebaliknya apabila nilai $W$ semakin mendekati 0 maka pendapat para responden semakin beragam. Koefisien konkordansi Kendall dihitung dengan rumus:

$$
R \mathrm{i}=\sum_{j=1}^{m} \mathrm{Ri}, \mathrm{j}
$$

Kemudian menghitung nilai rata-rata dengan rumus:

$$
\bar{R}=\frac{1}{n} \sum_{i=1}^{n} R_{i}
$$

Nilai kuadrat deviasi ditentukan dengan rumus :

$$
S=\sum_{i=1}^{n}\left(R_{i}-\bar{R}\right)^{2}
$$

Sehingga dapat ditentukan nilai Kendall's Coefficient sebagai berikut:

$$
W=\frac{12 S}{m^{2}\left(n^{3}-n\right)}
$$

\section{HASIL DAN PEMBAHASAN}

\section{a. Perencanaan Peningkatan Daya Saing Daerah}

Hasil pengumpulan dan pengolahan data menunjukkan bahwa peningkatan daya saing di provinsi Bengkulu telah direncanakan melalui rencana pembangunan jangka menengah daerah tahun 2010-2015 yang ditetapkan melalui peraturan daerah provinsi Bengkulu Nomor 3 Tahun 2014. Perencanaan peningkatan daya saing daerah tersebut dituangkan dalam empat misi pembangunan yakni Pertama, mewujudkan perekonomian rakyat yang berdaya saing. Langkah yang dilakukan untuk mewujudkannya adalah melalui perbaikan iklim investasi, menumbuhkembangkan perekonomian rakyat yakni bidang usaha mikro, kecil dan menengah serta mengembangkan dan meningkatkan sektor pertanian, perkebunan, peternakan dan perikanan. Kedua, daya saing daerah ditingkatkan melalui peningkatan kualitas dan kuantitas pelayanan pendidikan dan kesehatan masyarakat. Pada misi ketiga melalui pengelolaan kekayaan sumber daya alam dan pelestarian lingkungan, melakukan perbaikan infrastruktur dan menanggulangi resiko kerawanan terhadap bencana. Sedangkan pada misi keempat, peningkatan daya saing dilakukan dengan melaksanakan reformasi birokrasi dan menjaga stabilitas keamanan daerah.

Dari data tersebut maka sesungguhnya upaya untuk meningkatkan daya saing daerah telah dilakukan oleh pemerintah daerah provinsi Bengkulu, namun demikian upaya tersebut belum mencapai hasil yang optimal yang dibuktikan dengan masih tingginya angka kemiskinan dan angka pengangguran.

Usaha peningkatan daya saing daerah yang dilakukan pemerintah provinsi Bengkulu sesuai dengan teori daya saing daerah yang dikemukakan oleh Lengyel dan Rechnitzer (2013) yang menyatakan bahwa daya saing daerah (regional competitiveness) dibangun dan ditingkatkan melalui perbaikan faktor penentu keberhasilan dan faktor pembentuk daya saing yang tertuang dalam keempat misi pembangunan tersebut. Namun demikian peningkatan daya saing yang ditunjukkan oleh 
tingginya tingkat pendapatan daerah dan produktivitas tenaga kerja serta tingkat pengangguran yang rendah seperti yang dikemukakan Lengyel dan Rechnitzer belum dapat dicapai provinsi Bengkulu.

Kondisi ini menunjukkan bahwa perencanaan yang ditetapkan melalui rencana pembangunan jangka menengah daerah belum berhasil mencapai tujuannya sehingga perencanaan dapat dijadikan salah satu sudut pandang untuk menganalisis permasalah tersebut. Hasil wawancara menunjukkan bahwa permasalahan yang dihadapi dalam proses perencanaan adalah belum adanya standar minimal yang jelas tentang proses penyusunan rencana pembangunan. Standar tersebut terkait dengan kualifikasi pegawai yang ditugaskan untuk membahas, mengevaluasi dan menyusun rencana pembangunan baik yang telah maupun yang akan dilaksanakan. Standar kualifikasi pegawai ini penting karena kemampuan untuk mengkritisi usulan rencana pembangunan serta memberikan arahan yang tepat atas program yang diajukan akan berdampak positif bagi pembangunan daerah bukan hanya pada jangka pendek tetapi juga jangka panjang.

Hal lainnya berkaitan dengan standar yang digunakan dalam memonitoring dan mengevaluasi serta menyusun rencana pembangunan. Evaluasi yang dilakukan atas program pembangunan yangdilaksanakan lebih pada besaran penyerapan anggaran dan output yang berupa data-data kuantitatif serta mengabaikan outcome yang bersifat kualitatif sehingga evaluasi atas efektivitas program tidak optimal. Kondisi ini kemudian berpengaruh terhadap penetapan program pembangunan yang akan dilaksanakan pada tahun berikutnya yakni terkait dengan program yang harus dilanjutkan atau program yang dihentikan karena tidak diperlukan lagi atau tidak memberikan dampak yang signifikan pada perbaikan kondisi masyarakat.

Hal ini mendukung pendapat Faludi tentang teori prosedural dalam perencanaan. Faludi (1973:8) mengatakan bahwa salah satu masalah perencanaan adalah berkaitan dengan memahami perencanaan dan mendesain badan perencanaan serta prosedur yang ada di dalamnya. Untuk mengatasi masalah tersebut menurut Faludi (1973:11) badan perencana harus memiliki kerangka kerja (standar) yang jelas.

Selain itu, permasalahan perencanaan lainnya adalah belum memadainya kuantitas dan kualitas para perencana. Kurangnya tenaga perencana mengakibatkan beban kerja terlalu besar dan dengan kapasitas yang terbatas harus mampu mengerjakan berbagai perencanaan diluar bidang keahliannya. Keterbatasan tersebut pada akhirnya berdampak pada kualitas perencanaan.

$\mathrm{Hal}$ ini sesuai dengan pendapat yang dikemukakan oleh Faludi (1973:5) yang menyatakan bahwa bila perencanaan dipandang sebagai cara terbaik untuk mencapai tujuan, maka dapat dipahami bahwa meningkatkan pengetahuan pada bidang yang digelutinya menjadi perhatian yang paling besar bagi para perencana dengan asumsi bahwa tindakan yang benar hanya akan dihasilkan dari pemahaman yang baik.

\section{b. Prioritas Pembangunan untuk Meningkatkan \\ Daya Saing Daerah}

Hasil pengumpulan dan pengolahan data untuk menentukan prioritas pembangunan dalam meningkatkan daya saing di provinsi Bengkulu terdiri dari dua nilai yakni nilai normalized by cluster yakni nilai yang diperoleh atas perbandingan suatu indikator (elemen) dengan indikator lainnya dalam satu kluster dan nilai limiting yakni nilai yang diperoleh atas perbandingan suatu indikator (elemen) dibandingkan dengan indikator lain dari keseluruhan klaster.

Penentuan prioritas pembangunan dalam variabel ekonomi berdasarkan indikatorindikatornya diperoleh hasil bahwa sumber daya manusia $(0,18548)$ menjadi prioritas utama yang harus dibenahi untuk meningkatkan daya saing daerah provinsi Bengkulu diikuti dengan investasi $(0,17794)$, teknologi $(0,17114)$, inovasi $(0,16285)$, infrastruktur $(0,11136)$, modal $(0,11064)$ dan kinerja sektoral $(0,08059)$.

Tingkat kesepakatan atau persetujuan para respon atas hasil tersebut bernilai cukup baik. Nilai Kesepakatan tersebut dapat dilihat dari hasil perhitungan Kendall's Coefficient of Concordance(W) dengan nilai $W$ sebesar 0,48 atau sebesar 48 persen.

Grafik 1. Prioritas Para Responden Terhadap Faktor-Faktor Aspek Ekonomi

\begin{tabular}{|c|c|}
\hline Teknologi & 0.17114 \\
\hline SDM & 0.18548 \\
\hline Modal & 0.11064 \\
\hline Kinerja Sektoral & 0.08059 \\
\hline Investasi & 0.17794 \\
\hline Inovasi & 0.16285 \\
\hline Infrastruktur & 0.11136 \\
\hline
\end{tabular}


Hasil tersebut menunjukkan bahwa kualitas sumber daya manusia (tenaga kerja) merupakan masalah utama dalam meningkatkan daya saing daerah. Perbaikan kualitas tersebut berupa peningkatan keterampilan dan keahlian tenaga kerja sehingga mendorong tenaga kerja yang ada untuk tidak hanya sekedar mampu mendapatkan pekerjaan tetapi juga terdorong untuk membangun usaha atau menciptakan lapangan kerja baru.Masalah kedua adalah investasi. Investasi menjadi faktor penting terkait dengan masalah keterbatasan anggaran yang dimiliki pemerintah daerah dalam melaksanakan pembangunan dan masih minimnya kesempatan kerja yang ada di provinsi Bengkulu. Dengan demikian perlu dilakukan perbaikan iklim investasi atau iklim berusaha khususnya perbaikan pelayanan publik seperti perizinan usaha, penetapan peraturan yang jelas, persaingan yang sehat serta peminimalisiran praktek korupsi, kolusi dan nepotisme.

Kondisi investasi ini juga berkaitan dengan kualitas sumber daya manusia dan perbaikan infrastruktur karena salah satu kendala utama investasi di provinsi Bengkulu adalah rendahnya pengembalian sosial atas investasi yang dilakukan yang disebabkan lokasi yang tidak strategis, kondisi infrastruktur yang belum memadai dan sumber daya manusia yang rendah baik kuantitas maupun kualitasnya.

Dalam variabel sosial, indikator yang menjadi prioritas pertama adalah perbaikan kualitas pendidikan $(0,52992)$ dan diikuti dengan kesehatan $(0,35654)$, budaya $(0,06203)$ dan keamanan $(0,05151)$.

Grafik 2. Prioritas Para Responden Terhadap Faktor-Faktor Aspek Sosial

\begin{tabular}{|c|c|c|}
\hline Pendidikan & 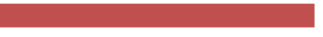 & 0.52992 \\
\hline Kesehatan & 0.35654 & \\
\hline Keamanan & 0.05151 & \\
\hline Budaya & 0.06203 & \\
\hline
\end{tabular}

Tingkat kesepakatan atau rater agreement para responden atas hasil yang diperoleh diatas bernilai baik dengan nilai Kendall's Coefficient of Concordance(W) adalah sebesar 0,58 atau 58 persen.

Berdasarkan hasil tersebut peningkatan kualitas pendidikan menjadi faktor penting dalam meningkatkan daya saing daerah di provinsi Bengkulu. Angka partisipasi sekolah penduduk menurun seiring dengan meningkatnya tingkat pendidikan. Penduduk yang menamatkan sekolah menengah atas pada umumnya lebih memilih untuk bekerja dibandingkan dengan meneruskan ke jenjang pendidikan sarjana. Dengan demikian pemerintah harus memberikan akses untuk membekali mereka dengan keterampilan dan keahlian yang sesuai dengan tuntutan dunia kerja disamping melakukan pemerataan kualitas pendidikan baik di kota maupun daerah.

Dalam variabel lingkungan, indikator yang menjadi prioritas adalah perbaikan dan pengoptimalan pengelolaan sumber daya alam $(0,69119)$ diikuti dengan lokasi $(0,26578)$ yakni berkaitan dengan lokasi daerah provinsi Bengkulu yang tidak strategis dan kondisi alam $(0,04303)$.

Grafik 3. Prioritas Responden Terhadap Faktor-Faktor Aspek Lingkungan

\begin{tabular}{|c|c|c|}
\hline Sumber Daya Alam & & 0.69119 \\
\hline Lokasi & 0.26578 & \\
\hline Kondisi Alam & 0.04303 & \\
\hline
\end{tabular}

Tingkat kesepakatan (rater agreement) para responden berdasarkan hasil perhitungan Kendall's Coefficient of Concordance(W) menunjukkan hasil yang cukup baik yakni dengan nilai W sebesar 0,40 atau sebesar 40 persen.

Pengoptimalan pengelolaan sumber daya alam menjadi prioritas dalam meningkatkan daya saing daerah di provinsi Bengkulu terutama dalam menghasilkan produk unggulan daerah yang mampu bersaing baik di tingkat nasional maupun internasional. Masalah lokasi yang tidak strategis berkaitan dengan aksesibilitas dan akan sangat dipengaruhi oleh faktor pembangunan dan perbaikan infrastruktur.

Untuk variabel kelembagaan pemerintah daerah, indikator yang menjadi prioritas adalah kebijakan pemerintah (0,31441). Selanjutnya adalah pengeluaran pemerintah $(0,28588)$, pelayanan publik $(0,23137)$ dan hambatan birokrasi $(0,16835)$.

Grafik 4. Prioritas Responden Terhadap Faktor-faktor dalam Aspek Kelembagaan Pemerintah

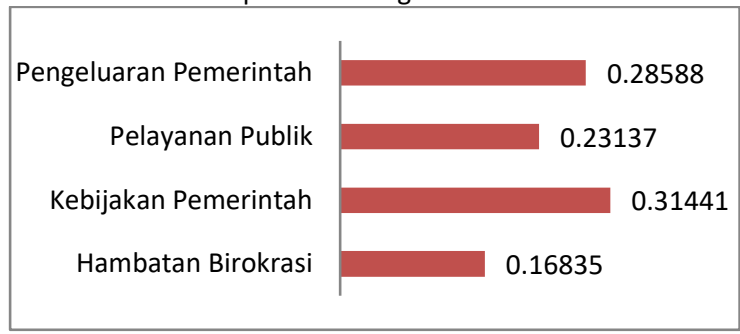


Nilai kesepakatan atau rater agreement para responden atas hasil tersebut cukup baik dengan nilai Kendall's Coefficient of Concordance(W) sebesar 0,41 atau 41 persen.

Hasil tersebut menunjukkan bahwa kebijakan pembangunan daerah melalui penetapan program-program pembangunan dinilai belum memberikan dampak yang signifikan dalam perbaikan tingkat daya saing daerah. Hal ini juga berkaitan dengan proses monitoring dan evaluasi yang belum berjalan dengan maksimal sehingga berdampak pada perencanaan program pembangunan pada tahun-tahun berikutnya.

Kebijakan lainnya juga berkaitan dengan pengeluaran pemerintah yakni pengalokasian anggaran yang harus diarahkan pada programprogram strategis. Kemampuan anggaran yang masih terbatas merupakan salah satu kendala yang dirasakan pemerintah daerah dalam melaksanakan program-program pembangunan. Namun demikian, pemilihan program yang tepat dan pemaksimalan alokasi anggaran pada program yang strategis dapat dilakukan untuk mengatasi masalah tersebut sehingga keluaran (output dan outcome) dari program tersebut dapat memberikan hasil yang baik bagi pembangunan daerah.
Pelayanan publik dan hambatan birokrasi menjadi prioritas berikutnya terkait dengan perbaikan kesejahteraan masyarakat khususnya perbaikan iklim berusaha atau iklim investasi di daerah. Rendahnya minat investor untuk menanamkan modal atau membuka usaha di provinsi Bengkulu pada umumnya disebabkan rumitnya pelayanan perizinan dan masih maraknya praktek korupsi, kolusi dan nepotisme yang selama ini menjadi hambatan dalam berhubungan dengan birokrasi di daerah. Kondisi demikian mengharuskan pemerintah daerah untuk mengurai hambatan birokrasi atau mengurangi praktek KKN dengan cara melakukan perbaikan pelayanan publik.

Perbaikan pelayanan publik tidak hanya terkait dengan jaminan pelayanan perizinan dan pelayanan umum lainnya yang tepat, cepat, mudah dan murah tetapi juga berkaitan dengan transparansi dan akuntabilitas pemerintah daerah yakni dengan memberikan akses yang seluas-luasnya bagi masyarakat untuk dapat memonitoring dan mengawasi kinerja pemerintah daerah. Oleh karena itu, perbaikan pelayanan publik menjadi prioritas bila dibandingkan dengan pemberantasan hambatan birokrasi dalam meningkatkan daya saing daerah di Provinsi Bengkulu.

Tabel 2. Hasil Prioritas Indikator-indikator Tiap Variabel Daya Saing Daerah

\begin{tabular}{|c|c|c|c|c|c|}
\hline Variabel (Klaster) & Indikator (Elemen) & $\begin{array}{c}\text { Normalized by } \\
\text { Cluster }\end{array}$ & Limiting & $\begin{array}{c}\text { Rank } \\
\text { Normalized }\end{array}$ & $\begin{array}{c}\text { Peringkat } \\
\text { Keseluruhan } \\
\text { (Limiting) }\end{array}$ \\
\hline \multirow{7}{*}{ Ekonomi } & D. Infrastruktur & 0,11136 & 0,058456 & 5 & 9 \\
\hline & E. Inovasi & 0,16285 & 0,085483 & 4 & 6 \\
\hline & F. Investasi & 0,17794 & 0,093404 & 2 & 4 \\
\hline & G.Kinerja Sektoral & 0,08059 & 0,042304 & 7 & 11 \\
\hline & H. Modal & 0,11064 & 0,058078 & 6 & 10 \\
\hline & I. SDM & 0,18548 & 0,097360 & 1 & 3 \\
\hline & J. Teknologi & 0,17114 & 0,089832 & 3 & 5 \\
\hline \multirow[t]{4}{*}{ Kelembagaan } & O.Hambatan Birokrasi & 0,16835 & 0,059522 & 4 & 8 \\
\hline & $\begin{array}{l}\text { P.Kebijakan } \\
\text { Pemerintah }\end{array}$ & 0,31441 & 0,111166 & 1 & 1 \\
\hline & Q.Pelayanan Publik & 0,23137 & 0,081805 & 3 & 7 \\
\hline & $\begin{array}{l}\text { R.Pengeluaran } \\
\text { Pemerintah }\end{array}$ & 0,28588 & 0,101078 & 2 & 2 \\
\hline \multirow[t]{3}{*}{ Lingkungan } & A.Kondisi Alam & 0,04303 & 0,002472 & 3 & 18 \\
\hline & B. Lokasi & 0,26578 & 0,015269 & 2 & 15 \\
\hline & C. SDA & 0,69119 & 0,039709 & 1 & 12 \\
\hline \multirow[t]{4}{*}{ Sosial } & K. Budaya & 0,06203 & 0,003974 & 3 & 16 \\
\hline & L. Keamanan & 0,05151 & 0,003300 & 4 & 17 \\
\hline & M. Kesehatan & 0,35654 & 0,022841 & 2 & 14 \\
\hline & N. Pendidikan & 0,52992 & 0,033948 & 1 & 13 \\
\hline
\end{tabular}

Berdasarkan nilai prioritas dari keselurahan indikator-indikator (nilai limiting) bila dibandingkan dengan keseluruhan variabel (kluster) maka perbaikan kebijakan pemerintah $(0,111166)$ menjadi prioritas pertama diikuti dengan pengalokasian pengeluaran pemerintah 
$(0,101078)$, perbaikan kualitas sumber daya manusia/tenaga kerja $(0,097360)$, perbaikan iklim dan peningkatan investasi $(0,093404)$, teknologi $(0,089832)$, inovasi $(0,085483)$, pelayanan publik $(0,081805)$, hambatan birokrasi $(0,059522)$ dan seterusnya yang dapat dilihat pada tabel 2 .

Perbandingan antar variabel (klaster) menunjukkan bahwa perbaikan kelembagaan pemerintah daerah $(0,51349)$ merupakan prioritas pertama dalam meningkatkan daya saing daerah provinsi Bengkulu diikuti dengan ekonomi $(0,27804)$, sosial $(0,13249)$ dan lingkungan (0,07598). Kesepakatan atau rater agreement atas hasil tersebut berdasarkan hasil perhitungan Kendall's Coeffiecient adalah sebesar 0,63 atau 63 persen yang berarti bahwa tingkat kesepakatan para responden baik.

Hasil tersebut membuktikan pendapat Lengyel dan Rechnitzer bahwa penentu suksesnya peningkatan daya saing daerah adalah decision maker (para pembuat keputusan) yakni pemerintah daerah. Perbaikan kelembagaan pemerintah daerah ini berkaitan dengan peningkatan kapasitas kelembagaan yakni peningkatan kapasitas aparatur, perbaikan prosedur yakni terkait dengan standar proses monitoring dan evaluasi yang jelas, memperkuat fungsi koordinasi dan penyusunan perencanaan yang didasarkan pada keakuratan data dan informasi serta perbaikan fungsi pemerintah khususnya dalam memberikan pelayanan publik yang mudah, murah, jelas dan cepat serta transparansi dan akuntabilitas terbuka bagi seluruh masyarakat.

Grafik 5. Prioritas Para Responden Terhadap Aspek Daya Saing Daerah

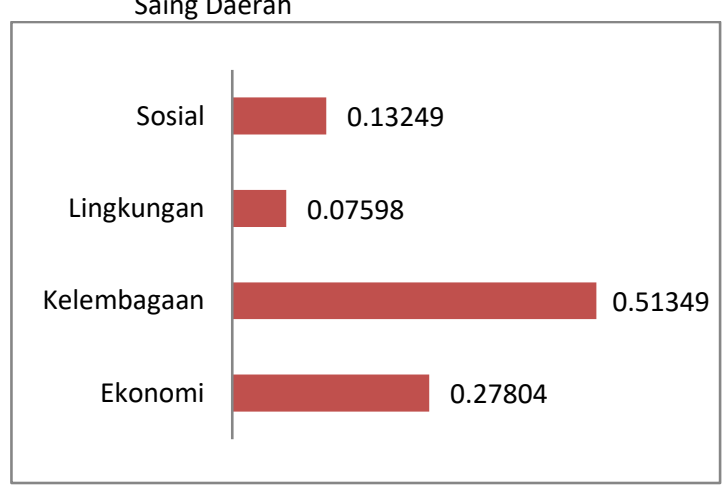

\section{KESIMPULAN}

Hasil penelitian menunjukkan bahwa perencanaan peningkatan daya saing di provinsi Bengkulu telah direncanakan dalam dokumen rencana jangka menengah daerah yang diuraikan dalam empat misi pembangunan yakni peningkatan ekonomi yang berdaya saing, perbaikan kuallitas sumber daya manusia, pengoptimalan pengelolaan sumber daya alam dan perbaikan infrastruktur serta pelaksanaan reformasi birokrasi. Tujuan pembangunan tersebut belum tercapai diantaranya disebabkan oleh terbatasnya kuantitas dan kualitas perencana, evaluasi dan monitoring yang tidak optimal serta koordinasi antarinstansi yang belum berjalan dengan baik.

Hasil perhitungan menunjukkan perbaikan kelembagaan pemerintah daerah merupakan prioritas dalam meningkatkan daya saing di provinsi Bengkulu diikuti dengan ekonomi, sosial dan lingkungan. Prioritas dalam kelembagaan pemerintah daerah adalah kebijakan pemerintah. Prioritas dalam ekonomi adalah sumber daya manusia, prioritas dalam sosial adalah pendidikan dan prioritas dalam lingkungan adalah pengelolaan sumber daya alam.

Keterbatasan penelitian ini adalah responden yang belum berasal dari tiap SKPD di pemerintah provinsi maupun pemerintah kabupaten/kota. Oleh karena itu, untuk peneliti selanjutnya dapat melakukan penelitian yang sama dengan menambah responden, menambah indikator yang digunakan, atau strategi yang dapat diterapkan untuk membangun masing-masing prioritas yang telah diperoleh dalam penelitian ini.

\section{DAFTAR PUSTAKA}

[1]. Krugman, Paul. 2003. Growth on the periphery: Second Winds for Industrial regions?. The Allander Series.

[2]. Tan, Khee G. Mulya Amri. 2013. Subnational Competitivenss and National Performance: Analysis and Simulation for Indonesia. Journal of CENTRUM Catedra (JCC): The Business and Economics Research Journal, Vo.6, Issue 2, hal. 173-192.

[3]. Charles,Vincent and Luis Felipe Zegarra. 2014. "Measuring Regional Competitiveness Through Data Envelopment Analysis: A Peruvian Case", Expert System with Applications,No.41:5371-5381.

[4]. Imawan, Rismawandha. 2002, Peningkatan Daya Saing: Pendekatan ParadigmatikPolitis, Jurnal IImu Sosial dan Politik, Vo.6 No.1 Juli. 
[5]. Lengyel, Imre and Janos Rechnitzer. 2013. The Competitiveness of Regions in The Central European Transition Countries. The Macrotheme Review 2 (4):106-121.

[6]. Martin, Ron. 2005. Thinking About Regional Competitiveness: Critical Issues, in Background 'Think-Piece' Paper Commissioned, East Midlands Development Agency UK, East Midlands.P.1-45.

[7]. Paul Plummer, et al, 2014, Endogenous Growth, Local Competitiveness and Regional Development: Western Australia's Regional Cities, 2001-2011, Journal of Economic and Social Policy, Vol.16, Issue 1.

[8]. Kumar, Arvind. 2001. Encyclopedia Of Decentralised Planning And Local SelfGovernance. Anmol Publication, New Delhi:India.

[9]. Faludi, Andreas. 1973. Planning Theory. Pergamon Press. Britain.

[10]. Saaty, Thomas L and Vargas, Louis G. 2006, Decision Making with the Analitic Network Process. Economic, Political, Social and Technological Applications with Benefits, Opportunities, Costs and Risks. Springer. RWS Publication: Pittsburgh.

[11]. Allmendinger,Philip. 2002. Towards A PostPositivist Typology of Planning Theory. Planning Theory,SAGE Publication Vol.1(1):77-99.

[12]. Berger,Thomas. $2013 . \quad$ Regional Development and Competitivenss-An Analysis of Indices of Regional Competitivenss, Cardiff University Departement of City and Regional Planning:UMI Dissertation Publishing.

[13]. Cheema,G.S dan Rondinelli, D.A. 2007. From Government Decentralization to Decentralized Governance, In G. Shabber Cheema and Dannies A. Rodinellsi (Eds). Decentralizing Governance: Emerging Concepts and Practices. Ash Institute for Democratic Governance and Innovation. Washington.

[14]. Riyadi, Deddy S.2004. Perencanaan Pembangunan Daerrah Strategi Menggali Potensi Dalam Mewujudkan Otonomi Daerah. Gramedia:Jakarta. 